\title{
Dietary Linoleic Acid and Glucose Enhances Azoxymethane-Induced Colon Cancer and Metastases via the Expression of High-Mobility Group Box 1
}

\author{
Hitoshi Ohmori Yi Luo Kiyomu Fujii Tomonori Sasahira Takasumi Shimomoto \\ Ayumi Denda Hiroki Kuniyasu \\ Department of Molecular Pathology, Nara Medical University, Kashihara, Japan
}

Key Words

Azoxymethane $\cdot$ Colorectal cancer $\cdot$ HMGB1 $\cdot$ Linoleic acid

\begin{abstract}
Objective: High-mobility group box 1 (HMGB1) was closely associated with progression and metastasis of colorectal cancer. Methods: We examined the significance of HMGB1 in causing colon carcinogenesis induced by azoxymethane (AOM) injection in Fischer 344 rats fed on a control diet (group C), a 15\% linoleic acid (LA) diet (group L), a control diet with $10 \%$ glucose drink (group G), and a 15\% LA diet with a $10 \%$ glucose drink (group $L+G$ ). Results: Group $L+G$ showed the highest body weight and calorie intake. Serum and mucosal HMGB1 levels were temporally increased in all groups, while the highest levels were observed in group L+G. Mucosal HMGB1 levels were correlated with cancer multiplicity and nodal metastases. In the AOM-injected rats fed the $15 \%$ LA diet with $10 \%$ glucose drink, administration of HMGB1 antibody suppressed serum HMGB1 concentration and cancer multiplicity. Conclusion: These data suggest that dietary LA and glucose provided the synergistic effect on AOM-induced rat colon cancer through HMGB1 induction.
\end{abstract}

Copyright $\odot 2010$ S. Karger AG, Basel
(C) 2010 S. Karger AG, Basel

$1015-2008 / 10 / 0774-0210 \$ 26.00 / 0$

Fax +4161306 1234 E-Mail karger@karger.ch www.karger.com

\section{Introduction}

Colorectal cancer (CRC) is the third leading cause of cancer in the Japanese population [1]. With the increasing Western influence on the diet of the Japanese people, the frequency of CRC has been continuously increasing [2]. In particular, the increase in dietary fat intake is considered to be a relevant factor for the increase in CRC. The effects of a high-fat diet on the predisposition to CRC depend on the source of oils. Dietary oils such as corn oil contain high amounts of linoleic acid (LA). The effects of this acid in synergy with azoxymethane (AOM) on rat colon mucosa were investigated, and it was found that LA in combination with $\mathrm{AOM}$ resulted in the upregulation of insulin-like growth factor-I/II receptors [3], ras protein [4] and cyclooxygenase-2 (COX-2) [5]; moreover, LA and $\mathrm{AOM}$ were also found to result in the activation of phospholipase $A_{2}$ and $C$, protein kinase $C$ [6] and farnesyl protein transferase, which function in the maturation of pro-ras [4]. In addition, they resulted in an increase in prostaglandin $\left(\mathrm{PGE}_{2}\right)$ production and proliferating cell nuclear antigen labeling indices [7], and a decrease in apoptosis [8]. Thus, it was concluded that a diet containing corn oil accelerates AOM-induced colon carcinogen-

Dr. Hiroki Kuniyasu

Department of Molecular Pathology, Nara Medical University

840 Shijo-cho

Kashihara, Nara 634-8521 (Japan)

Tel. +81 74422 3051, Fax +81 74425 7308, E-Mail cooninh@zb4.so-net.ne.jp 
esis $[4,5,7,8]$. In contrast to the effect of $\mathrm{LA}$, which is an n-6 polyunsaturated fatty acid (PUFA), n-3 PUFAs exhibit anti-carcinogenic effects on the colon mucosa [9]. In addition to increased lipid intake, overconsumption of sugar also contributes to diet-related health problems. Approximately $13.5 \%$ of the Japanese population suffers from diabetes or glucose intolerance [10]. In this study, we attempted to elucidate the synergic effect of highly unsaturated fatty acids, n-6 PUFA in particular, and sugar on the development and progression of CRC.

HMGB1, a structural protein in chromatin, is a cytokine associated with inflammation and cancer $[11,12]$. Induction of HMGB1 secretion by endotoxin shock enhances inflammatory responses [11, 13, 14]. Diverse effects of HMGB1 are provided by activation of the specific receptor called receptor for advanced glycation end products (RAGE). RAGE is a membrane receptor of the immunoglobulin superfamily, which is linked to serine/ threonine protein kinases [15, 16]. RAGE and HMGB1 are responsible for cancer progression and metastasis [1719]. Intracellular signals induced by RAGE activation are associated with cell proliferation, survival, migration, invasion, lysis of stroma, angiogenesis and generation of oxidative stress [17, 18, 20-24]. Cancer cells secrete high concentrations of HMGB1, which induces apoptosis in macrophage lineage cells and attenuates antimetastatic resistance [25-27].

In this study, we attempted to determine the significance of HMGB1 in the development and progression of CRC.

\section{Materials and Methods}

\section{Animals and Diets}

Five-week-old male Fischer 344 (F344) rats (Japan SLC, Shizuoka, Japan) were acclimatized for 1 week and then randomized into experimental and control groups. All animals were housed 4 per wide cage. The holding room was maintained at $23^{\circ} \mathrm{C}, 50 \%$ humidity, on a 12-hour light/dark cycle. A control diet (CE-2) was purchased from Clea (Tokyo, Japan). An experimental diet was prepared by mixing LA (Wako, Osaka, Japan) into the CE-2 diet $(15 \% \mathrm{w} / \mathrm{w})$. The study was approved by the Committee for Animal Experimentation of the Nara Medical University.

\section{Experimental Procedure}

At 5 weeks of age, groups of F344 rats (60 rats per group) were fed with the control diet (group C), high-LA diet (15\% LA in control diet, group L), high-glucose diet (10\% glucose drink and control diet, group $\mathrm{G}$ ) and high LA + high glucose diet (10\% glucose drink and 15\% LA in the control diet, group L+G). Body weight and food consumption were measured once a week throughout the experimental period. Rats were sacrificed under ether anes- thesia after cardiac blood collection $0,4,8,16,50$ and 70 weeks after the first AOM injection. The colon was removed, flushed with normal saline and opened from the cecum to anus to observe neoplastic lesions in all sacrificed rats. In each group, 5 of the 10 colons were fixed flat on a plastic plate in $10 \%$ buffered formalin for histological analysis. For analysis of protein and mRNA expression, the colon mucosae were scraped from the other 5 colons in each group, frozen in liquid nitrogen and stored at $-80^{\circ} \mathrm{C}$ until further analysis.

\section{Antibody Treatment}

A mouse monoclonal antibody for HMGB1 (R\&D Systems, Minneapolis, Minn., USA) was injected intraperitoneally at a dosage of $5 \mu \mathrm{g}$ in $500 \mu \mathrm{l}$ of PBS once a week from weeks 2 to 50 . The dosage neutralizing $100 \mathrm{ng} / \mathrm{ml}$ of HMGB1 in a rat weighing $400 \mathrm{~g}$ was calculated according to the concentration of serum HMGB1 data (fig. 1f).

\section{Sampling of Blood and Feces}

Rat blood was collected by cardiac centesis with a 23 -gauge needle. The blood was rapidly centrifuged at $500 \mathrm{~g}$ for $4 \mathrm{~min}$ at $4^{\circ} \mathrm{C}$. The supernatant was used as serum for further examinations. Fresh feces were obtained from the left colon. The feces were suspended in distilled water $(1: 5 ; \mathrm{w} / \mathrm{w})$ and centrifuged at 5,000 $\mathrm{g}$ for $5 \mathrm{~min}$ at room temperature. The supernatant was used as serum for further examinations.

\section{Enzyme-Linked Immunosorbent Assay for HMGB1}

ELISA kits were used to measure protein concentrations of HMGB1 (Shino-Test, Tokyo, Japan). Small pieces of tumor tissue $\left(\sim 10 \mathrm{~mm}^{3}\right)$ or non-tumoral mucosa $\left(\sim 16 \mathrm{~mm}^{2}\right)$ were obtained from each case, frozen in liquid nitrogen and stored at $-80^{\circ} \mathrm{C}$. The tissues were homogenized in lysis buffer $(50 \mathrm{~mm}$ Tris $\mathrm{HCl}, \mathrm{pH} 7.5$, $5 \mathrm{~mm}$ EDTA, $1 \mathrm{~mm}$ EGTA, 2\% Nonidet-40, $10 \mu \mathrm{g} / \mathrm{ml}$ leupeptin and $50 \mu \mathrm{g} / \mathrm{ml}$ phenylmethylsulfonyl fluoride) and centrifuged $(5,000 \mathrm{~g})$. The supernatant $(10 \mu \mathrm{g})$ was used for ELISA. The experiment was repeated twice.

In situ Hybridization

In situ hybridization (ISH) was performed as described previously [28-30] according to the Microprobe manual staining system (Fisher Scientific, Pittsburgh, Pa., USA). The sequence of the HMGB1 probe was 5'-GAG CAC AAG AAG AAG CAC CC-3' (GenBank Accession No. NM_012963.2). The probe was conjugated with fluorescein isothiocyanate at the $5^{\prime}$ end (synthesized by Sigma Genosys, Ishikari, Japan). The lyophilized probes were reconstituted to a $1-\mu \mathrm{g} / \mu \mathrm{l}$ stock solution in $10 \mathrm{mM}$ Tris $\mathrm{HCl}(\mathrm{pH}$ 7.6) and $1 \mathrm{~mm}$ EDTA. The stock solution was diluted with Probe Diluent (Research Genetics, Huntsville, Ala., USA) immediately before use. Formalin-fixed, paraffin-embedded specimens $(4 \mu \mathrm{m}$ thick) were mounted on silane-coated ProbeOn slides (Fisher Scientific). The slides were placed in the Microprobe slide holder, dewaxed and dehydrated followed by enzymatic digestion with pepsin (8 g/l 0.2 M HCl; DAKO, Glostrup, Denmark). Hybridization of the probe $(0.05 \mu \mathrm{g} / \mu$ l diluted with Probe Diluent) was carried out for $90 \mathrm{~min}$ at $55^{\circ} \mathrm{C}$, and the samples were then washed three times with $2 \times \mathrm{SSC}$ for $2 \mathrm{~min}$ at $45^{\circ} \mathrm{C}$. The slides were incubated in alkaline phosphatase-labeled anti-fluorescein isothiocyanate antibody (Dako) for $30 \mathrm{~min}$ at $37^{\circ} \mathrm{C}$, briefly rinsed in $50 \mathrm{mM}$ Tris buffer ( $\mathrm{pH}$ 7.6), rinsed with alkaline phosphatase enhancer 

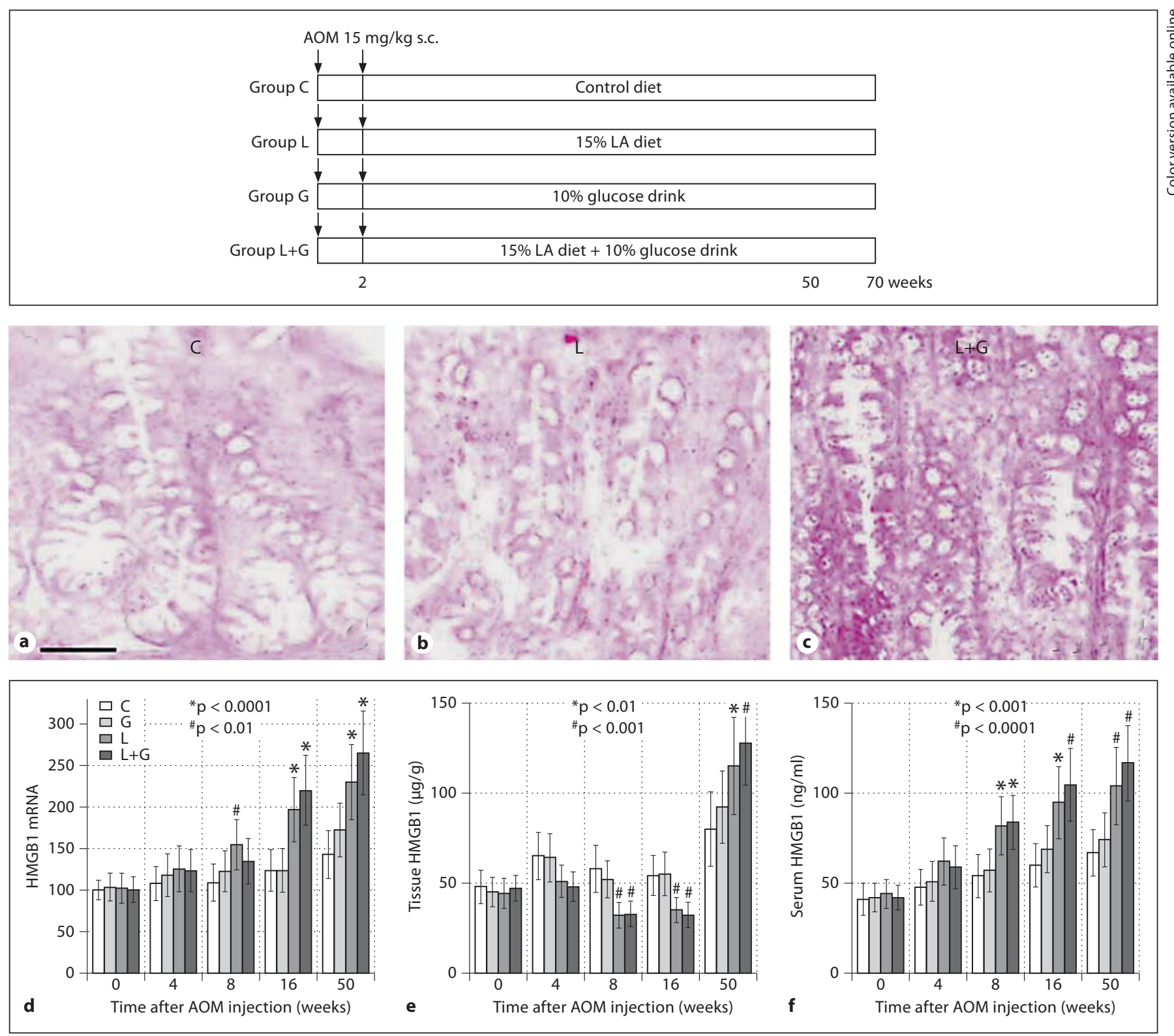

Fig. 1. Expressions of HMGB1 in the colonic mucosa of AOM-injected rats (upper panel). Protocol of the AOMinduced rat CRC model. a-c HMGB1 mRNA expression in the rat mucosa was examined by ISH in week 16. d-f Time course of the expression levels of mucosal HMGB1 mRNA (d), mucosal HMGB1 protein (e) and serum HMGB1 (f). C = Group C; G = group G; L = group L; L+G = group L+G. Bar = $50 \mu \mathrm{m}$. Error bar = SD. Statistical significance was calculated by comparing the values obtained in group $\mathrm{C}$ with those obtained in the remaining groups.

(Biomeda, Foster City, Calif., USA) for $1 \mathrm{~min}$, and finally incubated with chromogen substrate Fast Red (Research Genetics) for $30 \mathrm{~min}$ at $45^{\circ} \mathrm{C}$.

Reverse Transcriptase-Polymerase Chain Reaction

HMGB1 mRNA expression was assessed by RT-PCR using 0.5 $\mu \mathrm{g}$ total RNA extracted by RNeasy kit (Qiagen, Hilden, Germa- ny). Primer sets for rat HMGB1 amplification are: upper 5'-GAG CAC AAG AAG AAG CAC CC-3' and lower 5'-TAA CGA GCC TTG TCA GCC TT-3' (GenBank Accession No. NM_012963.2; synthesized by Sigma Genosys). PCR products were electrophoresed in $2 \%$ agarose gel and stained with ethidium bromide. $\beta$ Actin mRNA was also amplified for internal controls (GenBank Accession No. NM_001101). For semi-quantitation of HMGB1 
Table 1. Body weight and calorie intake of rats

\begin{tabular}{lcccc}
\hline & Group C & Group L & Group G & Group L+G \\
\hline Rats (week 70), n & 10 & 10 & 10 & 9 \\
Body weight (week 70), g & $353 \pm 38$ & $420 \pm 45^{\mathrm{a}}$ & $396 \pm 40^{\mathrm{b}}$ & $438 \pm 46^{\mathrm{a}}$ \\
Calorie intake, calories/week & $272 \pm 35$ & $375 \pm 42^{\mathrm{c}}$ & $453 \pm 51^{\mathrm{c}}$ & $455 \pm 53^{\mathrm{c}}$ \\
\hline
\end{tabular}

${ }^{\mathrm{a}} \mathrm{p}<0.005,{ }^{\mathrm{b}} \mathrm{p}<0.05,{ }^{\mathrm{c}} \mathrm{p}<0.0001$, vs. group $\mathrm{C}$ (Mann-Whitney U test). expression, signal densities of HMGB1 and $\beta$-actin were captured by Photoshop software (Adobe, San Jose, Calif., USA), and densitometric scanning was performed using National Institutes of Health (Bethesda, Md., USA) image software.

\section{Statistical Analysis}

Statistical significance was examined by the two-tailed Fisher's exact test, the two-tailed $\chi^{2}$ test and the two-tailed, unpaired Mann-Whitney U test using InStat software (Graphpad Software, Los Angeles, Calif., USA). Statistical significance was defined as a two-sided $\mathrm{p}<0.05$.

\section{Results}

\section{Body Weight and Calorie Intake of Rats}

The experimental protocol is shown in figure 1 (upper panel). AOM-injected F344 rats were divided into the following groups depending on their diet: the control diet group (group C), the 15\% LA diet group (group L), the $10 \%$ glucose drink group (group G) and the 15\% LA with $10 \%$ glucose drink group (group L+G). Each group comprised 60 rats; 10 rats were sacrificed $0,4,8,16,50$ and 70 after the first AOM injection, respectively. As shown in table 1 , in the rats belonging to group $\mathrm{L}+\mathrm{G}$, body weight and calorie intake were increased (24 and 67\%) 50 weeks after the AOM injection.

\section{HMGB1 Expression in Non-Neoplastic Mucosa}

HMGB1 expression was examined in the non-neoplastic mucosa of AOM-treated rats (fig. 1). HMGB1 mRNA expression was examined by ISH and RT-PCR, and HMGB1 protein concentration was measured in the whole lysate and serum. In the rats belonging to groups $\mathrm{L}+\mathrm{G}$ and $\mathrm{L}$, the level of HMGB1 mRNA was found to increase at weeks 16 and 50 (fig. 1a, d). In the rats belonging to groups $\mathrm{L}+\mathrm{G}$ and $\mathrm{L}$, a decrease in the level of tissue HMGB1 in the whole lysate was found at weeks 8 and 16 , followed by an increase in its level at week 50 (fig. 1e). In contrast, the serum HMGB1 level chronically increased in all the rats (fig. 1f). In particular, the rats in groups
$\mathrm{L}+\mathrm{G}$ and $\mathrm{L}$ showed a significant increase in the serum HMGB1 levels at weeks 8,16 , and 50 compared to those of group C.

\section{Development of Colon Adenocarcinoma}

All the AOM-injected rats developed adenocarcinoma of the colon (fig. 2a, b). Multiplicity of CRC in the rat was compared among the four groups 70 weeks after the AOM injection (table 2). The rats of groups $G, L$ and $L+G$ showed significantly higher multiplicity than those of group C. Higher multiplicity was observed in the rats belonging to group $\mathrm{L}+\mathrm{G}$ than in those belonging to groups $\mathrm{G}$ or $\mathrm{L}(\mathrm{p}<0.05)$. Only the rats belonging to groups $\mathrm{L}$ and $\mathrm{L}+\mathrm{G}$ developed mesocolonic lymph node metastases (fig. 2c, table 2); moreover, nodal metastases were found in 5 of 9 rats in group $L+G(p<0.05)$. Higher HMGB1 levels in the cancer tissues and mucosae were observed in rats of groups $\mathrm{G}, \mathrm{L}$ and $\mathrm{L}+\mathrm{G}$ than in those of group C. Especially in group $\mathrm{L}+\mathrm{G}$, the highest levels of HMGB1 were found in both cancer and mucosa $(\mathrm{p}<0.05)$. The HMGB1 concentrations in the mucosa and cancer correlated with cancer multiplicity by analyzing whole rats in all groups (Spearman $\mathrm{R}=0.91303, \mathrm{p}<0.0001$, and Spearman $\mathrm{R}=$ $0.93017, \mathrm{p}<0.0001$, respectively). Moreover, the rats with metastasized cancers, i.e. 5 rats in group $\mathrm{L}+\mathrm{C}$ and 1 rat in group L, showed higher HMGB1 levels in cancer tissue than rats with non-metastasized cancers $(179 \pm 15$ vs. $115 \pm 27 \mu \mathrm{g} / \mathrm{g} ; \mathrm{p}<0.0001)$.

\section{Suppression of HMGB1 in AOM-Injected Rats}

HMGB1 expression was suppressed using the specific antibody during AOM-induced CRC development (fig. 3). As shown in the experimental protocol (fig. 3a), the rats of group $\mathrm{L}+\mathrm{G}$ were re-examined with or without antibody treatment in comparison with those of group C. Antibody against HMGB1 was injected intraperitoneally once a week from weeks 2 to 50 (group HA). All the rats treated with AOM developed CRC. In group HA, cancer multiplicity was significantly decreased compared to that observed in group $L+G$ rats (fig. $3 b$ ). At 

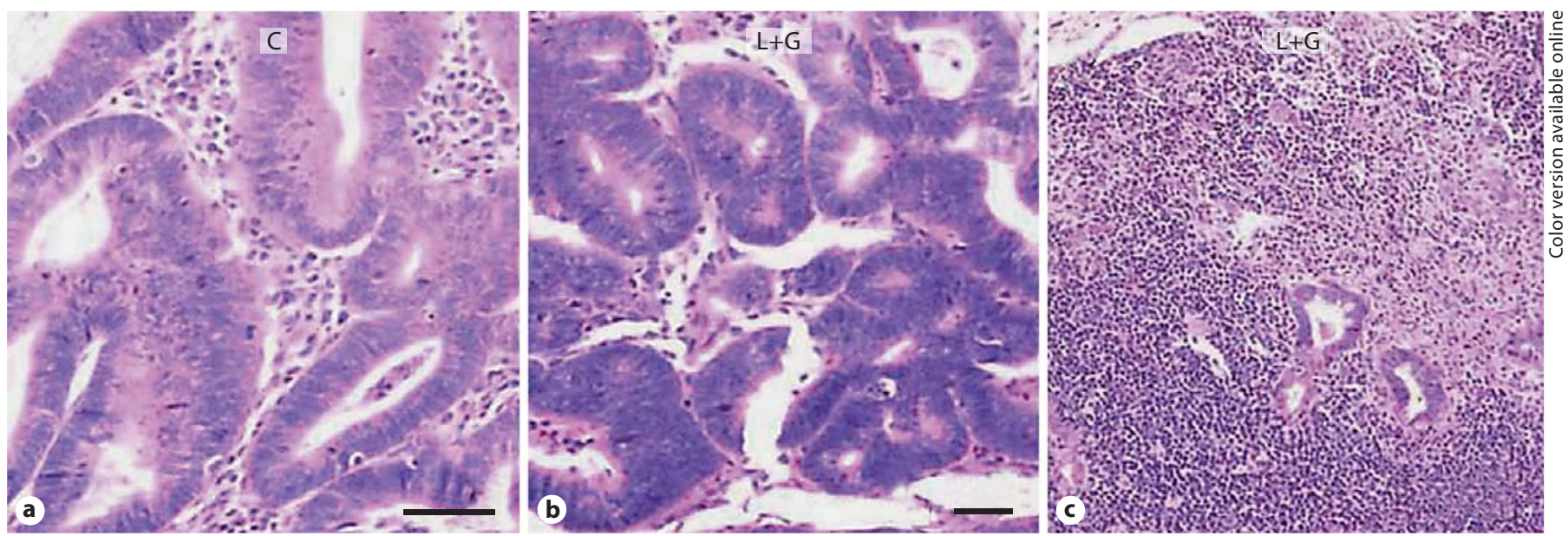

Fig. 2. HMGB1 expression in rat adenocarcinomas (a, b): histological appearance of colon adenocarcinoma in a group $C$ rat (a) and a group $L+G$ rat (b) 70 weeks after AOM injection. c Histological appearance of adenocarcinoma with mesocolonic lymph node metastasis in a group $\mathrm{L}+\mathrm{G}$ rat 70 weeks after $\mathrm{AOM}$ injection. Bar = $100 \mu \mathrm{m}$.

Table 2. Frequency of colon carcinoma and lymph node metastases in the rats

\begin{tabular}{lcccc}
\hline & Group C & Group L & Group G & Group L+G \\
\hline Rats (week 70), n & 10 & 10 & 10 & 9 \\
CRC, n/rat & $4.0 \pm 1.3$ & $7.3 \pm 1.6^{\mathrm{a}, \mathrm{f}}$ & $6.3 \pm 1.4^{\mathrm{b}, \mathrm{f}}$ & $9.0 \pm 1.9^{\mathrm{c}}$ \\
Nodal metastases, $\mathrm{n}$ & 0 & $1(10 \%)$ & 0 & $5(56 \%)^{\mathrm{d}}$ \\
HMGB1 concentration, $\mu \mathrm{g} / \mathrm{g}$ & & & & \\
$\quad$ Carcinoma & $82 \pm 21$ & $131 \pm 28^{\mathrm{b}, \mathrm{e}}$ & $118 \pm 28^{\mathrm{b}, \mathrm{e}}$ & $162 \pm 35^{\mathrm{c}}$ \\
$\quad$ Mucosa & $69 \pm 25$ & $108 \pm 32^{\mathrm{a}, \mathrm{e}}$ & $98 \pm 31^{\mathrm{a}, \mathrm{e}}$ & $136 \pm 38^{\mathrm{c}}$ \\
\hline
\end{tabular}

${ }^{\mathrm{a}} \mathrm{p}<0.001,{ }^{\mathrm{b}} \mathrm{p}<0.01,{ }^{\mathrm{c}} \mathrm{p}<0.0001$ (Mann-Whitney U test), and ${ }^{\mathrm{d}} \mathrm{p}<0.05$ (Fisher's exact test), vs. group C; ${ }^{\mathrm{e}} \mathrm{p}<0.05$ vs. group $\mathrm{L}+\mathrm{G}$ (Mann-Whitney $\mathrm{U}$ test).

weeks 16 and 50, the serum HMGB1 levels were significantly decreased in the rats belonging to group HA versus group $\mathrm{L}+\mathrm{G}$ (fig. 3c).

\section{Discussion}

In this study, we showed that HMGB1 levels were upregulated in the colonic mucosa of AOM-injected F344 rats. We had previously reported that HMGB1 is closely associated with colon cancer progression [19, 22]. HMGB1 activates RAGE intracellular signaling pathways involving $\mathrm{Rac} 1 / \mathrm{Cdc} 42$, extracellular signal-regulated kinase $1 / 2$, c-Jun N-terminal kinase, Bcl-2 and nuclear factor $\kappa B$ $[20,31,32]$. These pathways function to bring about accelerated growth and migration of cancer cells, and they suppress apoptosis, all of which contribute to the metastatic potential of cancer cells [17, 18, 22].

We showed that HMGB1 protein levels in the colonic mucosa and tumors were significantly increased in the rats belonging to groups $\mathrm{L}+\mathrm{G}, \mathrm{L}$ and $\mathrm{G}$ compared to that in the rats belonging to group C. In addition, the HMGB1 levels were correlated with cancer multiplicity. Lymph node metastases were more frequently detected in the rats of group $\mathrm{L}+\mathrm{G}$ than in those of group L. Moreover, the rats of groups $\mathrm{G}$ and $\mathrm{C}$ did not exhibit nodal metastases. Thus, the concurrent increase in HMGB1 levels in the rats of group $\mathrm{L}+\mathrm{G}$ at week 70 might be associated with lymph node metastases. We confirmed the higher RAGE expression in colon mucosa and carcinomas in group $\mathrm{L}+\mathrm{G}$ compared with groups $\mathrm{C}$, L, or G (data not shown). The highest levels of HMGB1 in tumors were detected in all 
Fig. 3. Effects of administration of antiHMGB1 antibody on AOM-injected rats. a Protocol of the experiment. b Multiplicity of adenocarcinomas in the rat colon at week 50. c Time course of serum HMGB1 in AOM-injected rats. $\mathrm{C}=$ Group $\mathrm{C}$; $\mathrm{L}+\mathrm{G}=$ group $\mathrm{L}+\mathrm{G}$; HA = group HA. Error bar $=\mathrm{SD}$. Statistical significance was calculated by comparing the values obtained in group L+G with those obtained in other groups.

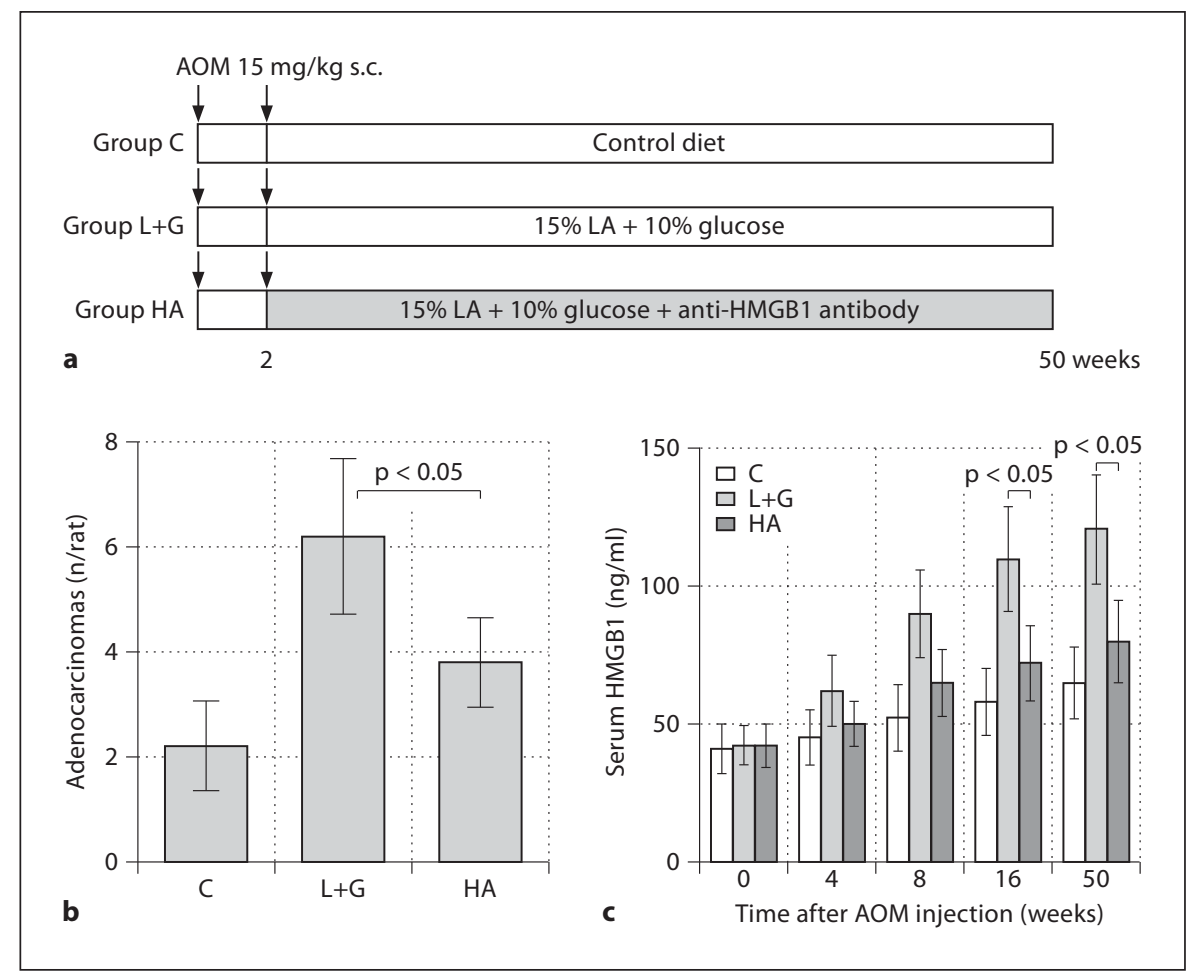

the 6 rats that exhibited nodal metastases in groups $\mathrm{L}+\mathrm{G}$ and L. In human cancers, RAGE and HMGB1 expression is significantly higher in metastatic than in non-metastatic gastric and colorectal cancers [18, 19].

We examined HMGB1 mRNA and protein levels in the mucosa and secretion. At weeks 8 and 16, there was a discrepancy between mucosal HMGB1 protein and mucosal HMGB1 mRNA or serum HMGB1; the levels of mucosal HMGB1 protein were lower than those in week 4, whereas the levels of mucosal HMGB1 mRNA or serum HMGB1 were higher than those in week 4 . The findings suggest that HMGB1 mRNA was upregulated; however, HMGB1 protein secretion into the serum was increased. The discrepancy was more pronounced in groups $\mathrm{L}$ and $\mathrm{L}+\mathrm{G}$ than in groups $\mathrm{C}$ and $\mathrm{G}$. The mechanism of translocation of HMGB1 from the nucleus to the cytosol, and its secretion from the cytosol to the extracellular spaces is still unclear. In monocytes, HMGB1 may be secreted via an atypical endolysosomal-like secretory pathway [33]. We have previously reported that deoxycholic acid upregulates HMGB1 expression and secretion [34]. It upregulates HMGB1 mRNA expression and induces $\mathrm{H} 4$ histone acetylation, which results in loosening of the chromatin structure and induces the translocation of HMGB1 from the nucleus to the cytosol $[34,35]$. Lepto- mycin B was found to inhibit the increase in the cytosolic HMGB1 concentration, suggesting that an active transport system might be involved in the translocation of HMGB1 from the nucleus to the cytosol [34]. In our models, groups $\mathrm{L}$ and $\mathrm{L}+\mathrm{C}$ showed an increase in the stool deoxycholic acid level (data not shown), which might be associated with increased HMGB1 secretion from the colon mucosa.

LA is known as a promoter of CRC carcinogenesis [36]. It is metabolized by COX-2 to produce prostaglandin, which induces chronic continuous inflammation associated with colon carcinogenesis [37]. In contrast, 15-lipoxygenase-1 metabolizes LA to produce peroxisome proliferator-activated receptor- $\gamma$ ligands, e.g. 13-hydroxyoctadecadienoic acid, which inhibit cell growth and induce apoptosis in epithelial cells [37]. During the transformation of human colon adenomas to adenocarcinomas, downregulation of 15-lipoxygenase-1 and upregulation of COX-2 occurred reciprocally in colon epithelial cells [38]. Induction of COX-2 has been confirmed by using a rat colon carcinogenesis model [39].

In the present study, the high-LA and high-glucose drink diet exhibited significant synergic effects on cancer multiplicity, metastases and upregulation of HMGB1. These two dietary factors are also strongly associated 
with the metabolic syndrome. The dietary control of these factors might be essential for CRC prevention. Moreover, our data of the significant effect of antiHMGB1 treatment on cancer development suggest a key concept of the molecular prevention of CRC.

\section{Acknowledgment}

This work was supported in part by a grant-in-aid for scientific research from the Japanese Society for the Promotion of Science, Japan.

\section{References}

1 Kato $\mathrm{H}$ (ed): Cancer Statistics in Japan (2008). Tokyo, National Cancer Center, 2008.

- 2 Inoue M, Iwasaki M, Otani T, Sasazuki S, Tsugane S: Public awareness of risk factors for cancer among the Japanese general population: a population-based survey. BMC Public Health 2006;6:2.

3 Zhang W, Thornton WH, MacDonald RS: Insulin-like growth factor-I and II receptor expression in rat colon mucosa are affected by dietary lipid intake. J Nutr 1998;128:158165.

4 Singh J, Hamid R, Reddy BS: Dietary fish oil inhibits the expression of farnesyl protein transferase and colon tumor development in rodents. Carcinogenesis 1998;19:985-989.

5 Singh J, Hamid R, Reddy BS: Dietary fat and colon cancer: modulation of cyclooxygenase- 2 by types and amount of dietary fat during the postinitiation stage of colon carcinogenesis. Cancer Res 1997;57:3465-3470.

-6 Rao CV, Simi B, Wynn TT, Garr K, Reddy BS: Modulating effect of amount and types of dietary fat on colonic mucosal phospholipase A2, phosphatidylinositol-specific phospholipase $\mathrm{C}$ activities, and cyclooxygenase metabolite formation during different stages of colon tumor promotion in male F344 rats. Cancer Res 1996;56:532-537.

7 Zhou S, Wang G, Chen B, Wang P: Effect of dietary fatty acids on tumorigenesis of colon cancer induced by methyl nitrosourea in rats. J Environ Pathol Toxicol Oncol 2000;19: 81-86.

$\checkmark 8$ Rao CV, Hirose Y, Indranie C, Reddy BS: Modulation of experimental colon tumorigenesis by types and amounts of dietary fatty acids. Cancer Res 2001;61:1927-1933.

-9 Reddy BS, Sugie S: Effect of different levels of omega- 3 and omega- 6 fatty acids on azoxymethane-induced colon carcinogenesis in F344 rats. Cancer Res 1988;48:6642-6647.

10 Neville SE, Boye KS, Montgomery WS, Iwamoto K, Okamura M, Hayes RP: Diabetes in Japan: a review of disease burden and approaches to treatment. Diabetes Metab Res Rev 2009;25:705-716.

11 Czura CJ, Wang H, Tracey KJ: Dual roles for HMGB1: DNA binding and cytokine. J Endotoxin Res 2001;7:315-321.
12 Degryse B, Bonaldi T, Scaffidi P, Muller S, Resnati M, Sanvito F, Arrigoni G, Bianchi ME: The high mobility group (HMG) boxes of the nuclear protein HMG1 induce chemotaxis and cytoskeleton reorganization in rat smooth muscle cells. J Cell Biol 2001;152: 1197-1206.

13 Fang WH, Yao YM, Shi ZG, Yu Y, Wu Y, Lu LR, Sheng ZY: The significance of changes in high mobility group-1 protein mRNA expression in rats after thermal injury. Shock 2002;17:329-333.

14 Yang H, Wang H, Tracey KJ: HMG-1 rediscovered as a cytokine. Shock 2001;15:247253.

15 Schmidt AM, Yan SD, Wautier JL, Stern D: Activation of receptor for advanced glycation end products: a mechanism for chronic vascular dysfunction in diabetic vasculopathy and atherosclerosis. Circ Res 1999;84: 489-497.

16 Huttunen HJ, Fages C, Kuja-Panula J, Ridley AJ, Rauvala H: Receptor for advanced glycation end products-binding $\mathrm{COOH}$-terminal motif of amphoterin inhibits invasive migration and metastasis. Cancer Res 2002;62: 4805-4811.

17 Taguchi A, Blood DC, del Toro G, Canet A, Lee DC, Qu W, Tanji N, Lu Y, Lalla E, Fu C, Hofmann MA, Kislinger T, Ingram M, Lu A, Tanaka H, Hori O, Ogawa S, Stern DM, Schmidt AM: Blockade of RAGE-amphoterin signalling suppresses tumour growth and metastases. Nature 2000;405:354-360.

18 Kuniyasu H, Oue N, Wakikawa A, Shigeishi H, Matsutani N, Kuraoka K, Ito R, Yokozaki $\mathrm{H}$, Yasui W: Expression of receptors for advanced glycation end-products (RAGE) is closely associated with the invasive and metastatic activity of gastric cancer. J Pathol 2002;196:163-170

19 Kuniyasu H, Chihara Y, Takahashi T: Coexpression of receptor for advanced glycation end products and the ligand amphoterin associates closely with metastasis of colorectal cancer. Oncol Rep 2003;10:445-448.
20 Huttunen HJ, Kuja-Panula J, Sorci G, Agneletti AL, Donato R, Rauvala H: Coregulation of neurite outgrowth and cell survival by amphoterin and S100 proteins through receptor for advanced glycation end products (RAGE) activation. J Biol Chem 2000;275: 40096-40105.

21 Kuniyasu $\mathrm{H}$, Chihara Y, Kondo H, Ohmori $\mathrm{H}$, Ukai R: Amphoterin induction in prostatic stromal cells by androgen deprivation is associated with metastatic prostate cancer. Oncol Rep 2003;10:1863-1868.

22 Kuniyasu H, Chihara Y, Kondo H: Differential effects between amphoterin and advanced glycation end products on colon cancer cells. Int J Cancer 2003;104:722-727.

-23 Bhawal UK, Ozaki Y, Nishimura M, Sugiyama M, Sasahira T, Nomura Y, Sato F, Fujimoto K, Sasaki N, Ikeda MA, Tsuji K, Kuniyasu $\mathrm{H}$, Kato $\mathrm{Y}$ : Association of expression of receptor for advanced glycation end products and invasive activity of oral squamous cell carcinoma. Oncology 2005;69:246-255.

24 Sasahira T, Kirita T, Bhawal UK, Ikeda M, Nagasawa A, Yamamoto K, Kuniyasu H: The expression of receptor for advanced glycation end products is associated with angiogenesis in human oral squamous cell carcinoma. Virchows Arch 2007;450:287-295.

25 Kuniyasu H, Yano S, Sasaki T, Sasahira T, Sone S, Ohmori H: Colon cancer cell-derived high mobility group 1/amphoterin induces growth inhibition and apoptosis in macrophages. Am J Pathol 2005; 166:751-760.

26 Kuniyasu H, Sasaki T, Sasahira T, Ohmori H, Takahashi T: Depletion of tumor-infiltrating macrophages is associated with amphoterin expression in colon cancer. Pathobiology 2004;71:129-136

27 Kusume A, Sasahira T, Luo Y, Isobe M, Nakagawa N, Tatsumoto N, Fujii K, Ohmori $\mathrm{H}$, Kuniyasu $\mathrm{H}$ : Suppression of dendritic cells by HMGB1 is associated with lymph node metastasis of human colon cancer. Pathobiology 2009;76:155-162.

28 Kuniyasu H, Ellis LM, Evans DB, Abbruzzese JL, Fenoglio CJ, Bucana CD, Cleary KR, Tahara E, Fidler IJ: Relative expression of E-cadherin and type IV collagenase genes predicts disease outcome in patients with resectable pancreatic carcinoma. Clin Cancer Res 1999;5:25-33. 
-29 Kuniyasu H, Troncoso P, Johnston D, Bucana CD, Tahara E, Fidler IJ, Pettaway CA: Relative expression of type IV collagenase, E-cadherin, and vascular endothelial growth factor/vascular permeability factor in prostatectomy specimens distinguishes organconfined from pathologically advanced prostate cancers. Clin Cancer Res 2000;6: 2295-2308.

-30 Kuniyasu H, Ukai R, Johnston D, Troncoso P, Fidler IJ, Pettaway CA: The relative mRNA expression levels of matrix metalloproteinase to E-cadherin in prostate biopsy specimens distinguishes organ-confined from advanced prostate cancer at radical prostatectomy. Clin Cancer Res 2003;9:2185-2194.
1 Schmidt AM, Hofmann M, Taguchi A, Yan SD, Stern DM: RAGE: a multiligand receptor contributing to the cellular response in diabetic vasculopathy and inflammation. Semin Thromb Hemost 2000;26:485-493.

32 Huttunen HJ, Fages C, Rauvala H: Receptor for advanced glycation end products (RAGE)-mediated neurite outgrowth and activation of NF- $\kappa \mathrm{B}$ require the cytoplasmic domain of the receptor but different downstream signaling pathways. J Biol Chem 1999;274:19919-19924.

33 Gardella S, Andrei C, Ferrera D, Lotti LV, Torrisi MR, Bianchi ME, Rubartelli A: The nuclear protein HMGB1 is secreted by monocytes via a non-classical, vesicle-mediated secretory pathway. EMBO Rep 2002;3: 995-1001.

-34 Fujii K, Luo Y, Sasahira T, Denda A, Ohmori $\mathrm{H}$, Kuniyasu $\mathrm{H}$ : Co-treatment with deoxycholic acid and azoxymethane accelerates the secretion of HMGB1 in IEC6 intestinal epithelial cells. Cell Prolif 2009;42:701-709.
35 Scaffidi P, Misteli T, Bianchi ME: Release of chromatin protein HMGB1 by necrotic cells triggers inflammation. Nature 2002; 418:191-195.

36 Kuniyasu H (ed): Linoleic Acid, ed 2. Berlin, Springer, 2008.

37 Kuniyasu H: The roles of dietary PPAR $\gamma$ ligands for metastasis in colorectal cancer. PPAR Res 2008;2008:529720.

38 Yuri M, Sasahira T, Nakai K, Ishimaru S, Ohmori H, Kuniyasu H: Reversal of expression of 15-lipoxygenase-1 to cyclooxygenase-2 is associated with development of colonic cancer. Histopathology 2007;51: 520-527.

39 Takahashi M, Wakabayashi K: Gene mutations and altered gene expression in azoxymethane-induced colon carcinogenesis in rodents. Cancer Sci 2004;95:475-480. 